\title{
PEMANFAATAN TIK DALAM PENINGKATAN BLENDED LEARNING GURU PENDIDIKAN AGAMA BUDDHA SMA DAN SMK DI TANGERANG
}

\author{
Heriyanto \\ Sekolah Tinggi Agama Buddha Negeri Sriwijaya Tangerang Banten \\ heriyanto@stabn-sriwijaya.ac.id
}

\begin{abstract}
Abstrak
Tujuan penelitian ini mendeskripsikan bagaimana pemanfaatan Teknologi Informasi dan Komunikasi (TIK) dalam peningkatan blended learning guru Pendidikan Agama Buddha SMA dan SMK di Tangerang. Penelitian berfokus pada pemanfaatan TIK dalam peningkatan metode pembelajaran yang digunakan guru Pendidikan Agama Buddha. Lebih spesifik pada metode blended learning guru Pendidikan Agama Buddha SMA dan SMK di Tangerang.

Jenis penelitian kualitatif dengan pendekatan eksploratif. Objek penelitian adalah bentuk-bentuk dan pola pemanfaatan TIK, serta metode blended learning guru Pendidikan Agama Buddha. Teknik pengumpulan data dengan teknik nontes. Peneliti sebagai instrumen utama dalam penelitian. Metode pengumpulan data dengan wawancara dan dokumentasi. Keabsahan data dilakukan dengan kredibilitas, dependabilitas, dan konfirmabilitas. Teknik analisis data dengan model Miles and Huberman.

Hasil penelitian menunjukan bentuk-bentuk pemanfaatan TIK guru Pendidikan Agama Buddha terdiri dari penggunaan smartphone dengan aplikasi pesan instan dan jejaring sosial, mengirim gambar dan foto melalui aplikasi jejaring sosial, mengakses dan menggunakan internet, serta membuat media pembelajaran. Pola pemanfaatan TIK guru Pendidikan Agama Buddha SMA dan SMK di Tangerang adalah sharing informasi, mengirim tugas dan materi pembelajaran, mencari materi pembelajaran, serta membuat media pembelajaran. Pemanfaatan TIK dalam peningkatan blended learning guru Pendidikan Agama Buddha SMA dan SMK di Tangerang terdiri dari pemanfaatan jejaring sosial, penggunaan teknologi internet, penggunaan email, dan membuat media pembelajaran berbasis multimedia interaktif.
\end{abstract}

TIK, Blended Learning, Metode Pembelajaran, Pendidikan Agama Buddha

\section{A. Pendahuluan}

Keberhasilan pembelajaran sangat bergantung pada cara guru dalam menggunakan metode pembelajaran. Dengan teknik penyajian yang dikuasai, metode pembelajaran harus sesuai dengan karakteristik siswa, kelas, dan tujuan pembelajaran. Kenyataan dimasyarakat, pentingnya metode pembelajaran tidak sepenuhnya dipahami oleh guru. Masih terdapat guru yang tidak menerapkan metode pembelajaran yang sesuai dengan karakteristik siswa, tidak sesuai dengan tujuan pembelajaran, serta metode kurang efektif dikarenakan tidak tersedianya alat dan bahan yang mendukung.

Guru merupakan komponen yang sangat penting dalam proses pembelajaran, guru profesional dengan terus mengikuti perkembangan dan kemajuan masyarakat akan membawa pada terbentuknya metode pembelajaran baru yang menggantikan metode konvensional, jika metode yang digunakan dianggap sudah tidak lagi relevan. Perkembangan TIK memberikan berbagai kemudahan akses informasi yang dapat 
dimanfaatkan guna mendukung metode pembelajaran, sumber belajar, dan bahan ajar. Dengan dukungan TIK, metode guru dalam pembelajaran tidak lagi hanya tatap muka (face to face) tetapi dapat juga dilakukan di luar kelas dengan bantuan dan berbagai media online.

Metode blended learning menyediakan pembelajaran dengan pendekatan teknologi kombinasi berbagai sumber dan media pembelajaran. Komputer dan internet melalui aplikasinya seperti website, blog, email, search engine, dan smartphone menjadi komponen penting dalam menciptakan berbagai metode campuran seperti blended learning. Dengan blended lerning terjadi penggabungan pembelajaran langsung (classroom), pembelajaran mandiri (self paced learning), pembelajaran online, kolaborasi (collaboration), dan penilaian (assessment). Berbagai bentuk kemudahan yang diberikan TIK tidak sepenuhnya menjadi kondisi sempurna untuk menciptakan dan implementasi metode blended learning. Masih terdapat guru dengan penguasaan teknologi yang rendah, belum memiliki kompetensi sesuai dengan kebutuhan untuk menerapkan pendekatan dan metode pembelajaran melalui pemanfaatan teknologi ${ }^{1}$. Masih terdapat guru yang merasa asing dengan fasilitas internet, email, blog dan website, serta rendahnya knowledge sharing.

Menyadari betapa pentingnya pendidikan agama, dalam proses pembelajaran Pendidikan Agama Buddha dibutuhkan berbagai sumber belajar, media, dan metode yang tepat. Perubahan paradigma pembelajaran dan perkembangan teknologi menuntut guru Pendidikan Agama Buddha untuk mampu mengubah pola dan metode pembelajaran. Pengetahuan agama yang kontekstual dan aplikatif tidak hanya didapatkan dari sumber kitab suci dan kurikulum, untuk mendapatkan pengetahuan agama yang komprehensif dibutuhkan knowledge dan kemampuan akses informasi melalui media internet. Belajar tidak hanya terjadi di ruang kelas (tatap muka), tetapi juga melalui lingkungan dan masyarakat yang memungkinkan terjadinya berbagai metode pembelajaran campuran seperti blended learning. Dalam pembelajaran Pendidikan Agama Buddha, selain sumber-sumber primer seperti kitab suci Agama Buddha dan kurikulum yang berlaku, dibutuhkan juga berbagai materi dan sumber belajar yang lebih lengkap guna tercapainya tujuan pembelajaran. Pada pelaksanaannya, proses pembelajaran Pendidikan Agama Buddha tidak berjalan pada tatanan yang maksimal. Dirasa masih terdapat kekurangan guru Pendidikan Agama Buddha dalam menerapkan metode pembelajaran dan menggunakan media pembelajaran dengan pemanfaatan $\mathrm{TIK}^{2}$.

Pemanfaatan TIK menjadi budaya masyarakat di kota Tangerang dengan tingkat penggunaan teknologi yang cukup tinggi. Sekolah-sekolah baru bermunculan dengan dukungan fasilitas lengkap khusunya internet dan website. Penggunaan berbagai fasilitas TIK di sekolah semakin menjadi kebutuhan, baik dalam mendukung administrasi maupun pembelajaran. Integrasi TIK dalam pembelajaran menjadikan pola penggunaan dan pemanfaatan TIK dalam meningkatkan berbagai metode pembelajaran yang digunakan guru. Penggunaan berbagai media online juga telah menjadi keseharian bagi siswa Sekolah Menengah Atas (SMA) dan Sekolah Menengah Kejuruan (SMK).

Melihat dukungan TIK yang begitu besar terhadap pembelajaran di sekolah serta keseharian guru dan siswa yang terbiasa dengan penggunaan berbagai aplikasi online,

\footnotetext{
${ }^{1}$ http://print.kompas.com/baca/2015/06/24/Guru-Dipaksa-Melek-Teknologi

${ }^{2}$ Observasi pada Pendidikan dan Pelatihan Profesi Guru (PLPG) Pendidikan Agama Buddha Tahun 2014
} 
menjadi latar belakang peneliti untuk melakukan penelitian dengan judul pemanfaatan TIK dalam peningkatan blended learning guru Pendidikan Agama Buddha di Tangerang. Bagaimana bentuk-bentuk dan pola pemanfaatan TIK dalam peningkatan blended learning guru Pendidikan Agama Buddha di Tangerang menjadi permasalahan tersendiri yang akan dideskripsikan dalam penelitian ini. Penelitian lebih difokuskan pada pemanfaatan TIK dalam peningkatan blended learning guru Pendidikan Agama Buddha SMA dan SMK di Tangerang.

\section{B. Kajian Teori}

\section{Pembelajaran}

Pembelajaran berpengaruh besar terhadap pemahaman seseorang. Pembelajaran merupakan rekonstruksi dari pengalaman masa lalu yang berpengaruh terhadap prilaku dan kapasitas seseorang atau kelompok ${ }^{3}$. Dalam pembelajaran seseorang terlibat dalam refleksi dan penggunaan memori untuk mempertimbangkan apa saja yang harus diserap, apa saja yang harus disimpan dalam memori, dan bagaimana seseorang menilai informasi yang telah diterima. Kegiatan pembelajaran yang dilakukan guru dan siswa merupakan sebuah proses yang terbentuk melalui berbagai model, pendekatan, dan metode pembelajaran. Pembelajaran pada dasarnya merupakan upaya untuk membantu siswa melakukan kegiatan belajar ${ }^{4}$. Untuk mencapai efektivitas dan tujuan yang telah ditentukan, pembelajaran dilakukan dengan menerapkan berbagai strategi, pendekatan, dan metode yang tepat.

\section{Metode Pembelajaran}

Perkembangan dan perubahan proses pembelajaran yang dinamis menuntut guru untuk selalu menyesuaikan pendekatan dan metode terhadap karakteristik dan perkembangan siswa. Metode pembelajaran merupakan perencanaan secara menyeluruh untuk menyajikan materi pembelajaran secara teratur, tidak ada satu bagian yang bertentangan, dan berdasarkan pada suatu pendekatan tertentu. Metode bersifat prosedural dengan penerapan dalam pembelajaran yang dilakukan melalui langkah-langkah sistematis dan teratur mulai dari penyusunan perencanaan pembelajaran, penyajian, proses pembelajaran, dan penilaian hasil belajar ${ }^{5}$. Metode pembelajaran merupakan sebuah cara yang digunakan oleh guru bersama-sama dengan siswa untuk mencapai tujuan pembelajaran yang telah ditetapkan. Pola hubungan dan interaksi guru dengan siswa pada saat terjadinya proses pembelajaran mencerminkan gambaran metode pembelajaran yang digunakan. Dengan menggunakan variasi beberapa metode, diharapkan terjadi pembelajaran yang tidak membosankan serta dapat mengatasi masalah yang dihadapi oleh guru dalam melaksanakan kegiatan dan proses pembelajaran.

\section{Blended Learning}

Berbagai model, pendekatan, metode, dan media harus terus dikembangkan oleh seorang guru untuk mencapai efektivitas pembelajaran. Blended learning

\footnotetext{
${ }^{3}$ Huda, Miftahul. 2013. Model-model Pengajaran dan Pembelajaran (isu-isu Metodis dan paradigmatis).Yogyakarta: Pustaka Pelajar.

${ }^{4}$ Isjoni. 2010. Pembelajaran Kooperatif. Yogyakarta: Pustaka Pelajar.

${ }^{5}$ Sudjana, Nana. 2005. Penilaian Hasil Proses Belajar mengajar. Bandung: PT. Remaja Rosdikarya.
} 
merupakan gabungan beberapa metode dan media dalam proses pembelajaran yang dilakukan oleh guru. Blended learning adalah metode belajar yang mengabungkan proses pembelajaran tatap muka dengan proses pembelajaran secara online yang terintegrasi secara optimal ${ }^{6}$. Blended learning perpaduan metode pembelajaran tatap muka dan metode pembelajaran online dengan bantuan berbagai media. Pemanfaatan media dalam blended learning dapat dilakukan melalui media online maupun media ofline (contoh menggunakan komputer yang tidak terhubung dengan koneksi internet). Metode blended learning didorong akan adanya berbagai kebutuhan fleksibilitas dalam proses pembelajaran yang tidak terpaku hanya pada lingkungan belajar di dalam kelas, proses pembelajaran dapat juga terjadi di luar kelas dengan pemanfaatan teknologi dan berbagai media TIK.

Khususnya dalam efektivitas pembelajaran, blended learning terus dikembangkan dengan menciptakan berbagai model, framework, dan menciptakan berbagai dukungan melalui infrastruktur teknologi. Metode blended learning memungkinkan terjadinya poses pembelajaran dan interaksi dengan guru melalui penggunaan berbagai media, khususnya media online yang dapat dilakukan kapan saja. Walau demikian, proses pembelajaran secara di dalam kelas (tatap muka) tetap menjadi bagian blended learning yang tidak dapat dihilangkan. Blended learning tidak hanya proses pembelajaran secara online dengan berbagai materi tersipan pada website, tetapi kolaborasi antara guru dan siswa harus juga terjadi secara tatap muka ${ }^{7}$. Secara umum, blanded learning memiliki tiga makna antara lain: (1) integrasi pembelajaran tradisional dengan pendekatan berbasis online; (2) kombinasi media dan peralatan pembelajaran, dan (3) kombinasi dari sejumlah pendekatan dan metode pembelajaran terlepas dari teknologi yang digunakan. Penggabungan (blended) lingkungan pembelajaran metode blended learning terdistribusi, meningkat, dan berkembang dengan cara eksponensial sebagai teknologi baru yang membentuk komunikasi dan interaksi dalam proses pembelajaran.

\section{Guru}

Dalam Undang-undang Republik Indonesia No. 14 Tahun 2005 tentang Guru dan Dosen, guru merupakan pendidik profesional dengan tugas utama mendidik, mengajar, membimbing, mengarahkan, melatih, menilai, mengevaluasi peserta didik pada pendidikan anak usia dini jalur pendidikan formal, pendidikan dasar, dan pendidikan menengah. Guru merupakan tenaga pendidik yang terkait dengan proses pembelajaran di sekolah. Guru Sekolah Menengah Atas (SMA) dan Sekolah Menengah Kejuruan (SMK) merupakan implementasi guru dalam menjalankan tugas pada satuan pendidikan formal tingkat pendidikan menengah.

Untuk menjalankan tugas, seorang guru wajib memiliki kompetensi pedagogik, kepribadian, sosial, dan kompetensi profesional. Kompetensi pedagogik merupakan kemampuan guru dalam pengelolaan pembelajaran. Kompetensi pedagogik guru juga meliputi perancangan pembelajaran, pelaksanaan

\footnotetext{
${ }^{6}$ Garrison dan Vaughan. 2008. Blended Learning in Higher Education (Framework, Principles, and Guidelines). San Francisco: JOSSEY-BASS, A Wiley Imprint.

${ }^{7}$ Stacey, Elizabeth dan Philippa Gerbic. 2009. Effective Blended Learning Practices: Evidence-Based Perspectives in ICT-Facilitated Education. Newyork. Information Science Reference.
} 
pembelajaran yang mendidik, dan pemanfaatan teknologi dalam pembelajaran. Sedangkan kompetensi profesional guru merupakan kemampuan guru dalam menguasai pengetahuan bidang ilmu pengetahuan, teknologi, dan/atau seni dan budaya $^{8}$. Profesionalisme guru menuntut guru untuk selalu berkembang mengikuti perkembangan zaman, perkembangan ilmu pengetauan dan teknologi, serta kebutuhan masyarakat.

\section{Guru Pendidikan Agama Buddha}

Dalam Peraturan Menteri Agama Nomor 16 Tahun 2010 tentang Pengelolaan Pendidikan Agama pada Sekolah, pendidikan agama adalah pendidikan yang memberikan pengetahuan dan membentuk sikap, kepribadian, dan keterampilan peserta didik dalam mengamalkan ajaran agamanya, yang dilaksanakan sekurangkurangnya melalui mata pelajaran pada semua jalur, jenjang dan jenis pendidikan. Guru pendidikan agama merupakan pendidik profesional dengan tugas utama mendidik, mengajar, membimbing, mengarahkan, melatih, memberi teladan, menilai, dan mengevaluasi peserta didik. Berkaitan dengan Pendidikan Agama Buddha, guru Pendidikan Agama Buddha memiliki tugas utama mendidik, mengajar, membimbing, mengarahkan, melatih, memberi teladan, menilai, dan mengevaluasi peserta didik melalui proses pembelajaran Pendidikan Agama Buddha di Sekolah.

Guru Pendidikan Agama Buddha jenjang SMA dan SMK merupakan guru yang menjalankan tugas profesi mengajar di sekolah tingkat pendidikan menengah. Dalam Peraturan menteri Pendidikan Nasional Nomor 16 Tahun 2007 Tentang Standar Kualifikasi Akademik dan Kompetensi Guru, kompetensi guru Pendidikan Agama Buddha meliputi menginterpretasikan dan menganalisis materi, struktur, konsep, dan pola pikir ilmu-ilmu yang relevan dengan pembelajaran Pendidikan Agama Buddha. Guru Pendidikan Agama Buddha melakukan proses pembelajaran di Sekolah pada mata pelajaran Agama Buddha sesuai dengan Kurikulum Pendidikan Agama yang ditetapkan. Dalam Kurikulum 2013, Pendidikan Agama Buddha di sekolah lebih dikenal dengan Pendidikan Agama dan Budi Pekerti. Guru Pendidikan Agama Buddha dan Budi Pekerti adalah guru Pendidikan Agama yang bertugas mengajar atau melakukan proses pembelajaran pada mata pelajaran Pendidikan Agama Buddha dan Budi Pekerti.

\section{Teknologi Informasi dan Komunikasi}

Teknologi Informasi dan Komunikasi (TIK), meliputi segala hal yang berkaitan dengan proses, penggunaan sebagai alat bantu, manipulasi, dan pengelolaan informasi. Teknologi Informasi dan Komunikasi (TIK) sebagai sebuah media atau alat bantu dalam memperoleh pengetahuan seseorang kepada orang lain ${ }^{9}$. Dengan TIK proses mendapatkan dan menyebarkan informasi menjadi semakin mudah. Komunikasi dengan bantuan berbagai media TIK dapat berlangsung satu arah maupun dua arah. TIK juga membentuk pola komunikasi dan interaksi secara langsung/real time (sinkronus) ataupun tidak langsung (asinkronus). Komunikasi

\footnotetext{
8 Peraturan Pemerintah Nomor.74 Tahun 2008, Tentang Guru.

9 Rusman. 2011. Model-model Pembelajaran, Mengembangkan Profesionalisme Guru. Jakarta: Raja Grafindo Persada.
} 
langsung dengan bantuan TIK dapat dilakukan dengan software/aplikasi seperti chat and mesenger, video call, dan media sosial (facebook, twitter). Sedangkan contoh komunikasi tidak langsung seperti email, forum, dan menulis pada website atau blog (blogger, wordpress).

Secara umum TIK lebih dikenal dengan Sistem Informasi (SI) dan Teknologi Informasi (TI). Salah satu peralatan TIK yang sangat diperlukan dalam berbagai bidang adalah komputer. Komputer mendukung terciptanya berbagai aplikasi yang memungkinkan terjadinya komunikasi dan interaksi. Bentuk TIK yang sedang berkembang pada masa sekarang adalah internet dan website dengan fungsi sebagai media sosial dan jejaring sosial, aplikasi chat, dan email. Smartphone juga merupakan sebuah alat yang dihasilkan dari kemajuan dan perkembangan TIK yang mendukung berbagai aplikasi dengan koneksi internet untuk terciptanya kolaborasi, interaksi, dan komunikasi real time.

\section{Metode Penelitian}

Penelitian ini merupakan penelitian kualitatif dengan pendekatan eksploratif. Objek penelitian adalah bentuk-bentuk dan pola pemanfaatan TIK, serta metode blended learning guru Pendidikan Agama Buddha. Teknik pengumpulan data dengan teknik nontes. Peneliti sebagai instrumen utama dalam penelitian. Metode pengumpulan data dengan wawancara dan dokumentasi. Keabsahan data dilakukan dengan kredibilitas, dependabilitas, dan konfirmabilitas. Teknik analisis data dengan model Miles and Huberman.

\section{Display Data Penelitian}

Bentuk dan pola pemanfaatan TIK guru Pendidikan Agama Buddha SMA dan SMK di Tangerang terlihat pada tabel 1 . Tabel 1 menggambarkan beberapa metode guru Pendidikan Agama Buddha dalam pembelajaran serta rencana pemanfaatan TIK yang akan dilakukan. Metode pembelajaran digunakan tidak hanya di dalam kelas tetapi juga dilakukan di luar kelas.

Tabel 1. Display Data Penelitian

\begin{tabular}{|l|l|}
\hline \multicolumn{1}{|c|}{ Bentuk Pemanfaatan } & \multicolumn{1}{|c|}{ Keterangan } \\
\hline Grup pembelajaran siswa & \\
\hline Grup Smartphone & Grup dengan menggunakan smartphone \\
\hline Grup Line & \\
\hline Grup Blackberry & \\
\hline Diskusi pembelajaran pada grup & \\
\hline Kirim tugas melalui grup & \\
\hline Foto pada media sosial & Grup dan chat \\
\hline WhatsApp & \\
\hline Menggunakan internet & \\
\hline Menggunakan email & \\
\hline Email materi & \\
\hline Email tugas & Bertanya melalui sms dan telepon \\
\hline Sms dan telepon & Mengumpulkan tugas dengan fashdisk \\
\hline Menggunakan flashdisk & Search Engine Google \\
\hline Searching materi & \\
\hline Membuat video, gambar, film & \\
\hline Upload video tugas & Membuat slide PowerPoint untuk memberikan \\
\hline Membuat media PowerPoint &
\end{tabular}




\begin{tabular}{|c|c|}
\hline \multicolumn{2}{|l|}{ Pola Pemanfaatan } \\
\hline Deskripsi & Keterangan \\
\hline \multicolumn{2}{|l|}{ Sharing informasi } \\
\hline \multicolumn{2}{|l|}{ Kirim materi pembelajaran } \\
\hline \multicolumn{2}{|l|}{ Mencari bahan materi pembelajaran } \\
\hline Tugas dalam Pembelajaran & $\begin{array}{l}\text { Menyelesaikan, membuat tugas dalam } \\
\text { pembelajaran }\end{array}$ \\
\hline Kirim tugas & Menggunakan grup \\
\hline Bertanya materi dan tugas & Bertanya ketika kelas telah selesai \\
\hline Membuat media & Membuat media oleh guru maupun siswa \\
\hline Penggunaan TIK dalam pembelajaran & $\begin{array}{l}\text { Penggunaan fasilitas sarana dan prasarana TIK } \\
\text { sekolah dalam pembelajaran }\end{array}$ \\
\hline \multicolumn{2}{|l|}{ Blended Learning } \\
\hline $\begin{array}{c}\text { Deskripsi } \\
\end{array}$ & $\begin{array}{l}\text { Keterangan } \\
\end{array}$ \\
\hline $\begin{array}{l}\text { Tugas, proyek, dan mencari materi } \\
\text { pembelajaran di luar kelas }\end{array}$ & Selain pembelajaran di dalam kelas \\
\hline Pembelajaran kelas & Pembelajaran di dalam kelas \\
\hline Penugasam multimedia & Penugasan kolaborasi dengan guru pelajaran lain \\
\hline Sekolah minggu & Mengambil nilai pada sekolah minggu \\
\hline \multicolumn{2}{|l|}{ Perencanaan } \\
\hline $\begin{array}{r}\text { Deskripsi } \\
\end{array}$ & Keterangan \\
\hline Rencana membuat aplikasi & Sistem dan program \\
\hline Penggunaan Blog & Blog sebagai media pembelajaran \\
\hline
\end{tabular}

\section{E. Pembahasan}

\section{Bentuk-bentuk Pemanfaatan TIK Guru Pendidikan Agama Buddha di Tangerang}

Bentuk pemanfaatan TIK guru Pendidikan Agama Buddha SMA dan SMK di Tangerang terdiri dari penggunaan smartphone dengan aplikasi pesan instan dan jejaring sosial, mengirim gambar dan foto dengan aplikasi jejaring sosial, mengakses dan menggunakan internet, serta membuat media pembelajaran.

Teknologi yang mendukung pembelajaran pada SMA dan SMK di Tangerang diantaranya personal computer, laptop, LCD Proyektor, internet, dan handphone. Smartphone merupakan handphone yang memiliki kemampuan dan fungsi seperti sebuah komputer. Tidak hanya untuk mengirim pesan instan dan telepon, smartphone dengan sistem operasi menyediakan berbagai aplikasi yang mendukung berbagai kebutuhan. Koneksi internet pada smartphone menjadikan search engine, email, dan aplikasi jejaring sosial (Blackberry Messenger, Line, dan WhatsApp) dapat diakses dengan mudah.

Penggunaan jejaring sosial pada smartphone menjadi bentuk pemanfaatan TIK yang utama digunakana guru Pendidikan Agama Buddha SMA dan SMK di Tangerang. Dengan jejaring sosial, diskusi pembelajaran antara guru dan siswa tetap berlangsung walaupun jam pembelajaran di dalam kelas telah berakhir. Komunikasi secara pribadi ataupun grup dimanfaatkan guru dan siswa dalam pembelajaran Pendidikan Agama Buddha untuk melakukan diskusi kelas dan diskusi berkaitan dengan materi pembelajaran. Bagi guru dapat mengirim tugas 
dan memberikan informasi pembelajaran. Mengirim gambar berupa foto materi pembelajaran antara siswa satu dengan siswa lainnya juga dapat dilakukan. Menyerahkan tugas siswa kepada guru dapat dilakukan melalui grup pada jejaring sosial. Informasi yang diberikan guru melalui grup terkait dengan pembelajaran dapat dalam bentuk informasi tambahan materi pembelajaran, batas mengumpulkan tugas, informasi tidak ada jam pelajaran, dan juga jawaban atas pertanyaan siswa berkaitan dengan tugas yang diberikan di kelas. Tidak selalu komunikasi dan diskusi secara formal, fasilitas grup dan chat juga digunakan untuk sekadar saling menyapa dan mengobrol.

Perkembangan dunia internet yang begitu pesat telah terintegrasi dalam berbagai aspek masyarakat. Dalam dunia pendidikan, internet menjadi sumber-sumber informasi tanpa batas. Pemanfaatan internet dalam pembelajaran, mengkondisikan siswa belajar lebih mandiri. Proses pembelajaran tidak terbatas oleh waktu seperti halnya pembelajaran tatap muka di dalam kelas. Kolaborasi, sharing dan bertukar informasi dalam pembelajaran dapat terjadi dengan pemanfaatan internet. Email merupakan aplikasi dan sarana untuk mengirim surat secara elektronik dengan menggunakan jaringan internet. Guru Pendidikan Agama Buddha menggunakan email sebagai alat untuk melakukan pertukaran informasi dan materi pembelajaran. Mengirim materi pembelajaran berupa slide PowerPoint merupakan salah satu bentuk pemanfaatan email oleh guru Pendidikan Agama Buddha SMA dan SMK di Tangerang. Oleh siswa, email juga dijadikan alat untuk menyerahkan dan mengumpulkan tugas kepada guru.

Internet berperan penting dalam pengembangan materi pembelajaran. Prinsip kecukupan materi pembelajaran menjadikan guru terus memperbaiki, mengidentifikasi jenis-jenis bahan pembelajaran, dan memilih materi pembelajaran yang sesuai. Berangkat dari prinsip kecukupan materi pembelajaran, guru terus memperbaiki, mencari fakta relevan, mencari bahan, dan mencari media pembelajaran dengan memanfaatkan internet. Begitu juga dengan siswa, beberapa tugas diberikan berupa tugas membuat makalah, video bertema buddhis, dan gambar buddhis yang tentunya membutuhkan pemanfaatan internet dan software untuk membuat. Khusus pada SMK jurusan multimedia seperti SMK Atisa Dipamkara, beberapa tugas diberikan berupa proyek multimedia yang juga merupakan penugasan gabungan beberapa mata pelajaran. Metode dalam menyerahkan tugas juga berbeda-beda untuk setiap guru, sehingga menjadikan bentuk pemanfaatan TIK yang berbeda. Untuk file berkapasitas besar menyerahkan tugas dapat dilakukan dengan flashdisk, dan upload video, sedangkan file dengan kapasitas kecil seperti makalah dapat diserahkan dengan menggunakan email.

Pembelajaran tidak terlepas dari dukungan media pembelajaran. Prilaku guru Pendidikan Agama Buddha SMA dan SMK di Tangerang dalam menciptakan dan mencari media pembelajaran menjadikan bentuk-bentuk pemanfaatan TIK tersendiri. Video Riwayat Hidup Buddha Gotama, film Angulimala, dan slide PowerPoint merupakan contoh media pembelajaran yang biasa digunakan guru Pendidikan Agama Buddha SMA dan SMK di Tangerang.

\section{Pola Pemanfaatan TIK Guru Pendidikan Agama Buddha di Tangerang}


Pola pemanfaatan TIK guru Pendidikan Agama Buddha di Tangerang adalah sharing informasi, mengirim tugas dan materi pembelajaran, mencari materi pembelajaran, serta membuat media pembelajaran. Pola pemanfaatan TIK oleh guru berkaitan erat dengan kebutuhan fungsional, pendekatan, dan teknik membawakan materi dalam pembelajaran. Kebutuhan tidak hanya kebutuhan individu, melainkan kebutuhan proses fungsional dan operasional. Kebutuhan guru untuk meningkatkan kualitas pembelajaran melalui proses dan hasil pembelajaran menjadikan guru menentukan strategi, metode, alat, dan sumber belajar yang tepat dan sesuai karakteristik siswa.

Sharing informasi berkaitan dengan pembelajaran merupakan cara yang dilakukan guru untuk mendukung pembelajaran dengan pemanfaatan fasilitas, sarana, dan prasarana sekolah. Sharing informasi merupakan kebutuhan akan terpenuhinya informasi pembelajaran untuk siswa, tidak terbatas hanya pada pembelajaran di dalam kelas. Batas menyerahkan tugas, petunjuk mengerjakan tugas, dan pertanyaan meteri pembelajaran menjadi informasi yang di share oleh guru kepada siswa. TIK menjadi alat yang dimanfaatkan guru untuk melakukan sharing dan memberikan informasi kepada siswa.

Perubahan paradigma pendidikan dan kemajuan teknologi membawa dampak terhadap proses pembelajaran. Strategi dan metode pembelajaran telah mengubah pendekatan pembelajaran tradisional kearah pembelajaran yang dapat berlangsung dimana saja dan kapan saja. Mengirim tugas dan materi pembelajaran, merupakan pendekatan yang dilakukan guru untuk mengakomodir kebutuhan dan perkembangan paradigma pendidikan. Teknologi, khusnya pemanfaatan TIK menjadi keharusan untuk mengakomodir kebutuhan proses pembelajaran yang tidak hanya terjadi di dalam kelas. Integrasi proses pembelajaran di dalam kelas dan di luar kelas terjadi melalui berbagai bentuk-bentuk pemanfaatan TIK.

Untuk memenuhi aspek kecukupan, berbagai usaha guru dilakukan untuk menambahkan dan memperluas materi ajar. Pemanfaatan TIK khusunya teknologi internet merupakan pola yang dilakukan guru untuk menambahkan dan mencari materi pembelajaran. Tidak hanya itu, aspek relevansi dan kesesuaian berbagai fakta dengan pembelajaran Pendidikan Agama Buddha menjadikan guru harus terus mengembangkan materi pembelajaran, tentunya dilakukan dengan berbagai pola dan bentuk pemanfaatan TIK.

Media tidak terpisahkan dalam proses pembelajaran. Materi pembelajaran dapat disampaikan dengan berbagai media. Media Pembelajaran dapat memperjelas penyajian pesan yang disampaikan dalam memberikan materi pembelajaran. Kebutuhan guru akan media pembelajaran, menjadikan guru memanfaatkan berbagai TIK untuk menciptakan berbagai media, termasuk multimedia. Media visual, audio, dan video merupakan bentuk nyata produk TIK yang dapat dimanfaatkan dalam pembelajaran. Dengan kebutuhan yang begitu besar terhadapat media pembelajaran, menjadi pola dan keseharian guru memanfaatkan TIK untuk mencari dan membuat media pembelajaran, khususnya media pembelajaran Pendidikan Agama Buddha.

\section{Pemanfaatan TIK dalam Peningkatan Blended Learning Guru Pendidikan Agama Buddha SMA dan SMK di Tangerang}


Pemanfaatan TIK oleh guru Pendidikan Agama Buddha dalam mendukung blended learning terdiri dari pemanfaatan jejaring sosial, penggunaan teknologi internet, penggunaan email, dan membuat media pembelajaran berbasis multimedia interaktif. Pembelajaran tatap muka di dalam kelas memiliki beberapa kekurangan, terbatas oleh waktu, dan lebih berpusat pada guru. Metode pembelajaran dengan menggabungkan berbagai media online diharapkan dapat meningkatkan hasil belajar siswa dengan proses pembelajaran yang berlangsung kapan saja dan dimana saja. Salah satu media yang dapat dimanfaatkan sebagai sarana pembelajaran blended learning adalah aplikasi jejaring sosial. Jejaring sosial menjadi pilihan utama dikarenakan perkembangan media dan jejaring sosial yang begitu pesat, sangat familiar dengan siswa, dan menjadi keseharian siswa.

Dengan jejaring sosial pembelajaran tidak hanya terbatas di kelas, diskusi pada grup, chat antar guru dan siswa, mengirim file, dan mengirim gambar dapat dilakukan di luar kelas. Dengan jejaring sosial pembelajaran tetap dapat terjadi walaupun tidak di dalam kelas dan tidak tatap muka langsung. Sebagai media komunikasi yang menghasilkan kolaborasi, diskusi pembelajaran, dan sharing informasi, menjadikan jejaring sosial sebagai sebuah metode online yang mendukung pembelajaran. Dengan demikian pembelajaran di dalam kelas yang tergabung dengan berbagai proses pembelajaran di luar kelas akan meningkatkan efektivitas metode yang digunakan guru dalam proses pembelajaran. Metode guru dalam memberikan pembelajaran tatap muka di dalam kelas terintegrasi dengan metode guru yang digunakan dengan bantuan jejaring sosial online membentuk sebuah metode campuran dalam pembelajaran.

Berbagai bentuk aplikasi jejaring sosial seperti Blackberry Messenger, Line, dan WhatsApp memiliki fitur mengirim file berbentuk dokumen, gambar, audio, dan video. Mengirim tugas dilakukan guru Pendidikan Agama Buddha dalam bentuk chat teks dalam grup yang terhubung kepada semua siswa yang bergabung. Sedangkan untuk mengirim pesan yang sifatnya hanya informasi, seperti informasi tidak ada pembelajaran untuk hari tertentu, batas mengumpulkan tugas, dan informasi hari libur dilakukan dengan fitur broadcast. Dukungan berbagai fitur dan fungsi jejaring sosial memungkinkan proses pembelajaran dapat terjadi dimana saja dan kapan saja. Jejaring sosial membentuk kolaborasi, diskusi, dan sharing informasi menjadikan jejaring sosial berkontribusi besar terhadap peningkatan berbagai aktivitas pendukung metode blended learning guru Pendidikan Agama Buddha.

Internet membentuk individual learning, aktif membangun pengetahuan sendiri, secara subjektif, dinamis, dan berkembang. Guru Pendididikan Agama Buddha memanfaatkan internet untuk memenuhi aspek kecukupan materi pembelajaran. Materi pembelajaran terus dikembangkan guna mencapai standar kompetensi yang ditetapkan. Knowledge guru terus bertambah dengan mengakses sumbersumber informasi, yang secara langsung akan berpengaruh terhadap kompetensi profesional. Guru Pendidikan Agama Buddha SMA dan SMK di Tangerang menggunakan internet untuk mencari dan memperluas materi pembelajaran, menyajikan berbagai video dan film yang relevan dengan materi pembelajaran Pendidikan Agama Buddha. Search engine Google memberikan kemudahan untuk mencari berbagai informasi yang dibutuhkan. Untuk mencari berbagai video relevan terhadap pembelajaran Pendidikan Agama Buddha, Youtube menjadi 
website yang sering digunakan. Internet juga menjadi media transmisi mengirim materi pembelajaran atau bahan ajar kepada siswa. Mengirim materi pembelajaran dapat dilakukan dengan pemanfaatan internet melalui email dan sebuah jejaring sosial. Bagi siswa, internet digunakan untuk menyerahkan tugas melalui email dan melakukan upload beberapa tugas sesuai dengan petunjuk guru.

Pemanfaatan internet oleh guru Pendidikan Agama Buddha SMA dan SMK di Tangerang menunjang peningkatan kualitas pembelajaran di dalam kelas. Walaupun kegiatan pembelajaran utama adalah tatap muka di dalam kelas, peranan internet adalah menyediakan sumber-sumber belajar dengan cara memberikan alamat berbagai sumber belajar yang sesuai dan dapat diakses secara online. Internet meningkatkan kuantitas, memperluas kesempatan berkomunikasi, kolaborasi, dan diskusi antara guru dengan siswa.

Email digunakan dalam proses pembelajaran untuk mengirim materi dan menyerahkan tugas siswa kepada guru. Pemberian tugas dengan metode menyerahkan melalui email memberikan kesempatan kepada siswa untuk berkreasi dan kreatif. Beberapa tugas pembelajaran Pendidikan Agama Buddha pada SMA dan SMK di Tangerang berbentuk makalah yang dapat dengan mudah dikirimkan melalui email. Penugasan tidak hanya terjadi di dalam kelas tetapi dapat di luar kelas dengan fleksibilitas jarak dan waktu. Dengan email, tugas dapat dikirim dan diterima dari mana dan kapan saja. Waktu tugas dikumpulkan dan tanggal suatu tugas dikirimkan secara otomatis tercatat pada email, sehingga ketepatan waktu dan pengadministrasian tugas akan menjadi lebih baik dan terstruktur. Berbagai kemudahan dan kontribusi postitif penggunaan email, membawa efektivitas dan peningkatan pembelajaran guru dengan media online.

Proses membuat dan mencari media pembelajaran yang sesuai dengan tujuan dan karakteristik siswa menciptakan bentuk-bentuk pemanfaatan teknologi bagi guru. Media pembelajaran dapat digunakan langsung pada pertemuan tatap muka di dalam kelas atau diberikan kepada siswa melalui berbagai cara. Media pembelajaran dapat dikirimkan melalui email atau menggunakan media penyimpanan data seperti flashdisk. Guru Pendidikan Agama Buddha SMA dan SMK di Tangerang menggunakan dan membuat media pembelajaran berbasis multimedia interaktif berupa slide PowerPoint. Fungsi media pembelajaran sedemikian rupa, membawa kesempatan besar membentuk metode baru yang menjadi trigger diskusi dan kolaborasi pembelajaran di luar kelas, dapat juga komunikasi secara online melalui email dan grup pembelajaran pada jejaring sosial. Media pembelajaran memungkinkan terjadinya proses pembelajaran walaupun tidak melakukan tatap muka di dalam kelas. Sedangkan untuk memenuhi kebutuhan komunikasi akibat proses pembelajaran yang terjadi dengan media, maka tercipta interaksi siswa dan guru, bahkan siswa dengan siswa melalui berbagai jenis teknologi internet secara online.

Tabel 2. Pemanfaatan TIK dalam Peningkatan Blended Learning Penggunaan jejaring sosial (Membentuk berbagai aktivitas pendukung blended learning)

Diskusi pembelajaran pada chat dan grup

Mengirim materi oleh guru dan mengirim tugas oleh siswa

Sharing informasi dengan broadcast

Penggunaan teknologi internet (Pelengkap kebutuhan metode tatap muka di dalam kelas) 


Individual learning
Aspek kecukupan materi pembelajaran
Peningkatan kompetensi profesional
Penghubung metode pembelajaran campuran
Akses sumber-sumber informasi
Penggunaan email
Fleksibilitas jarak dan waktu
Administrasi tugas lebih terstruktur (waktu mengirim dan menyerahkan tugas tercatat)
Membuat media pembelajaran multimedia interaktif
Aktivitas belajar multimedia
Materi dapat dipelajari di luar kelas
Diskusi melalui media online
Kolaborasi melalui media online
Interaksi melalui media online

\section{F. Kesimpulan}

Bentuk pemanfaatan TIK guru Pendidikan Agama Buddha terdiri dari penggunaan smartphone dengan aplikasi pesan instan dan jejaring sosial, mengirim gambar dan foto dengan aplikasi jejaring sosial, mengakses dan menggunakan internet, serta membuat media pembelajaran. Pola pemanfaatan TIK guru Pendidikan Agama Buddha SMA dan SMK di Tangerang adalah sharing informasi, mengirim tugas dan materi pembelajaran, mencari materi pembelajaran, serta membuat media pembelajaran. Pemanfaatan TIK dalam peningkatan blended learning guru Pendidikan Agama Buddha SMA dan SMK di Tangerang terdiri dari pemanfaatan jejaring sosial, penggunaan teknologi internet, penggunaan email, dan membuat media pembelajaran berbasis multimedia interaktif.

\section{G. Referensi}

Akhmad Sudrajat. 2008. Pengertian Pendekatan, Strategi, Metode, Teknik, dan Model Pembelajaran. http://akhmadsudrajat.word.press.com (diakses 11 Desember 2015).

Akkoyunlu, B., dan Soylu, M. Y. 2008. A Study of Student's Perceptions in a Blended Learning Environment Based on Different Learning Styles. Educational Technology \& Society.

Aulia, Luki. 2015. Guru Dipaksa Melek Teknologi. http://print.kompas.com/ baca/2015/06/24/Guru-Dipaksa-Melek-Teknologi (diakses 4 Januari 2016).

Barizi, Ahmad dan Muhammad Idris. 2010. Menjadi Guru Unggul. Jogjakarta: ArRuzz Media.

Benthall, Nigel. 2008. Blended Learning: Setting the Course for the "Crew Change".

Carman, Jared. M. 2005. Blended Learning Design: Five Key Ingredients. http://www.agilantlearning.com/pdf/Blended\%20Learning\%20Design.pdf (diakses 2 Februari 2016)

Cunningham, Amanda. 2016. Is blended learning same technology rich instruction?. http://www.getfueled.com/ blog/2016-01-28/blended-learning-same-technologyrich-instruction (diakses 28 Januari 2016).

Garrison dan Vaughan. 2008. Blended Learning in Higher Education (Framework, Principles, and Guidelines). San Francisco: JOSSEY-BASS, A Wiley Imprint. 
Sandi, Gede. 2012. Pengaruh Blended Learning terhadap Hasil Belajar Kimia Ditinjau dari Kemandirian Siswa. Jurnal Pendidikan dan Pengajaran, Jilid 45, Nomor 3,Oktober 2012, hlm 241-251. Universitas Pendidikan Ganesha.

Huda, Miftahul. 2013. Model-model Pengajaran dan Pembelajaran (isu-isu Metodis dan paradigmatis).Yogyakarta: Pustaka Pelajar.

Isjoni. 2010. Pembelajaran Kooperatif. Yogyakarta: Pustaka Pelajar.

Jamal, Ma'mur Asmani. 2011. Tips Efektif Pemanfaatan Teknologi Informasi dan Komunikasi dalam Dunia Pendidikan. Jogjakarta: Diva Press.

Kitchenham, Andrew. 2011. Blended Learning across Disciplines: Models for Implementation. United States of America: Information Science Reference (an imprint of IGI Global).

Napitupulu, Ester Lince. 2015. 2015. Mutu Guru Belum Menggembirakan. http://print.kompas.com/baca/2015/07/07/Mutu-Guru-Belum-Menggembirakan (diakses 24 Januari 2016).

Peraturan Menteri Pendidikan Nasional Nomor 16 Tahun 2007, Tentang Standar Kualifikasi dan Kompetensi Guru.

Peraturan Menteri Pendidikan Nasional Republik Indonesia Nomor 16 Tahun 2007, Tentang standar Kualifikasi Akademik dan Kompetensi Guru.

Peraturan Pemerintah Nomor.74 Tahun 2008, Tentang Guru.

Prabowo, Hengki Tri. 2014. Implementasi Model Pembelajaran Blended Learning untuk Meningkatkan Aktivitas Belajar Multimedia Siswa Kelas XI Multimedia 1 SMK Muhammadiyah 2 Klaten Utara Tahun Ajaran 2013/2014. Skripsi. Fakultas teknik. Program Studi Teknik Informatika. Universitas Negeri Yogyakarta.

Putra, Sitiatava Rizema. 2013. Desain Belajar Mengajar Kreatif Berbasis Sains. Yogyakarta: Diva Press.

Rossett, Allison, Felicia Douglis, and Rebecca V. Frazee. 2003. Strategies for Building Blended Learning. http://ejournalafrica06.blogspot.co.id/ 2006/10/howto-deliver-effective-blended.html (diakses 2 Februari 2016).

Rusman. 2011. Model-model Pembelajaran, Mengembangkan Profesionalisme Guru. Jakarta: Raja Grafindo Persada.

Sjukur, Sulihin B. Sjukur. 2012. Pengaruh Blended Learning terhadap Motivasi Belajar dan Hasil Belajar Siswa Tingkat SMK. Jurnal Pendidikan Vokasi, Vol 2, Nomor 3. Program Pascasarjana Universitas Negeri Yogyakarta.

Stacey, Elizabeth dan Philippa Gerbic. 2009. Effective Blended Learning Practices: Evidence-Based Perspectives in ICT-Facilitated Education. Newyork. Information Science Reference.

Sudjana, Nana. 2005. Penilaian Hasil Proses Belajar mengajar. Bandung: PT. Remaja Rosdikarya.

Susanto. 2002. Sistem Informasi Manajemen: Konsep dan Pengembangannya. Bandung: Linga Jaya.

Syarif, Izuddin . 2012. Pengaruh Penerapan Model Blended Learning terhadap Motivasi dan Prestasi Belajar Siswa SMKN 1 Paringin. Tesis, Program Pascasarjana. Universitas Negeri Yogyakarta.

Tu’u, Tulus. 2004. Peran Disiplin Pada Prilaku dan Prestasi Siswa. Jakarta: Grasindo.

Undang-undang Republik Indonesia No. 14 Tahun 2005 tentang Guru dan Dosen. 